This species occurs, long before snow has gone, in large colonies, under loose wet bark and under soil, in crevices at the base of a tree. Although most common on pine, it lives also on elm and apple. In mild weather, it wanders about on the trunks of trees or on the ground, and it occurred in enormous numbers as a "snow-flea," in Maryland, as recorded above. Captive specimens

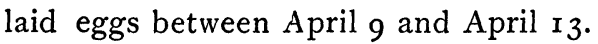

On April r 2, I found abundant eggs of this species among a colony of adults at the base of a white pine; the eggs were white, spherical, and deposited in irregular heaps.

I have never been able to find this species in its customary haunts at any time of the year after April I2; it is probably at least digoneutic, however, and may prove to be dimorphic.

\title{
ON THE LIMITS OF THE FAMILY SATURNIIDAE, WITH A NOTE ON THE GENUS ROTHSCHILDIA.
}

BY A. S. PACKARD, PROVIDENCE, R. I.

The elimination of so many non-spinning genera from the Saturniidae as proposed in this paper leaves that family very much curtailed.

As I pointed out some years ago, ${ }^{*}$ it is divided into two subfamilies, of very simple larval characters, i. e., whether the two dorso-median tubercles of the 8th abdominal segment of the larva remain separate, or are united in a single median one.

The subfamily Saturniinae, characterized by having six separate tubercles (the two median ones being separate) on the 8th abdominal segment, comprise the following genera, Perisomena, Cricula, Saturnia (I cannot see that Calo-

* Studies on the transformation of moths of the family Saturniidae. Proc. Amer. Acad. Arts and Sciences, Boston, (n. s.) XX, p. 58.1893. saturnia mendocino differs from Saturnia), Heniocha, Loepa.

The subfamily Attacinae was at the same time characterized by the larvae having but five tubercles on the 8 th abdominal segment, the median one being double, resulting from the fusion of the tubercles belonging to the two dorsal series. The imaginal characters bear out this arrangement.

The following genera belong to this group, beginning as heretofore with the most generalized forms, the exact sequence being subject to farther modification: Copaxa, Opodiphtera, Tagoropsis, Syntherata, Rhodia, Rinaca, Neoris, Caligula, Graellsia, Argema, Actias, Tropaea, Antheraea, Telea, Metosamia, Callosamia, Samia, Epiphora, Philosamia, Rothschildia, Coscinocera, Attacus. 
This subfamily is divided into several, at least five groups of genera, in two series, for example a Copaxa group, an Antheraea group (Antheraea, Telea, Metosamia); a Samia group (Samia, Epiphora, Callosamia) a Tropaea group (Graellsia, Argema, Actias, Tropaea), and an Attacus group (Rothschildia, Philosamia, Attacus).

Whether Rhodia, Rinaca, and Neoris belong with Loepa, which has six tubercles on the 8th abdominal segment, or with Copaxa which in stage I has but five, the median one being double, reremains to be seen after we know more of their larval forms.

\section{Note on the genus Rothschildia.}

As originally written, I had proposed a new generic name for the American Moths referred to Attacus.*

This name was proposed by $\mathrm{Mr}$. Grote for the American, chiefly Naeogaeic, species heretofore referred to Attacus. The latter genus, comprising Attacus atlas, $A$. crameri and $A$. edwardsiz, is restricted to southeastern Asia and the East Indian Archipelago or the oriental region. In fact it is much more closely related to Philosamia than to Rothschildia.

From a study of the venation and

* After this article was put in type and a day before receiving the proof, I received by $\mathrm{Mr}$. Grote his excellent article, Beitrag zur Classification der Schmetterlinge, I896, in which he separates the American species of Attacus under the name of Rothschildia. I therefore suppress the generic name I had proposed. The characters he gives are essentially what I have pointed out in the present article. We seem, quite independently of each other, to have arrived at the same results. other features of six species of Rothschildia, it becomes quite evident that the new world or naeogaeic species form a group readily separated from the speciès of Attacus of the Oriental region, both by the larval and imaginal characters, though in the general appearance of the moths, the shape of the wings and markings there is a close resemblance.

Rothschildia differs from Attacus in the following characters; the antennae have pectinations nearly one-half shorter, and the end of the antenna is subfiliform; the palpi are 3-jointed, those of Attacus I-jointed; the fore tibial epiphysis is in Rothschildia narrow, very sharp at the end, about half as wide as in Attacus, in which ( $A$. atlas) it is oval, and the end obtuse.

The fore wings are less falcate than in Attacus, and the hind wings more rounded at the inner angle, not so triangular in outline as in Attacus, nor so much produced posteriorly: indeed they are closely like those of Philosamia.

In the venation the difference between the Asiatic and American forms is striking; in all the Rothschildiae examined there is no first subcostal vein (or vein II.). In Attacus atlas, crameri, and edreardsii the first branch of the subcostal vein is fully developed, arising at a point near the middle of the discal cell, i.e., within the origin of the common stalk of the other subcostal branches. In this respect it is closely allied to Philosamia, where vein II is present. Vein $\mathrm{II}_{2}$ is minute, very short ; $\mathrm{II}_{3}$ present, normal. In Rothschildia vein II is wanting, $\mathrm{II}_{2}$ 
is a little longer than in Attacus and the other veins of the wings are as in Attacus. The venation of the hind wings is nearly the same in both genera. The wonderful similarity of markings, especially the large, clear discal spots in genera quite remote is an interesting case of convergence.

The larva of Rothschildia approaches Samia, rather than Attacus. That of $A$. atlas has been well described and carefully figured in all stages by M. Poujade, (Annales Soc. Ent. France, X, I880; p. I83, Pl. 8.)

The larva of Attacus atlas in its final stage is provided with long finger-shaped tubercles; those, however, on the tergum of the $2 \mathrm{~d}$ and $3 \mathrm{~d}$ thoracic segments are very different in shape, being large, short and rounded, those on the abdominal segments long and slender. Reduction occurs on the thoracic segments only; the two rows of tubercles on the sides of the thoracic segments are of the same shape, but a little longer than those on the abdominal segments.

In Rothschildia, as shown by blown examples of Rothschildia orizaba received from Mexico, the tubercles are more rudimentary; they are low, short, fleshy, and are crowned with 5-7 small sharp spinules, while those of Attacus atlas are long, finger-shaped and unarmed with any spinules. The median tubercle on the 8th abdominal segment is very small, inconspicuous, and but slightly larger than the other dorsal tubercles of the abdominal segments. The dorsal tubercles on the meso- and metathoracic segments are scarcely larger, if any, than those in the abdominal segments.

Burmeister has figured the larvae of Rothschildia hesperus, ethra, aurota, betis, and speculifer. In all except $R$. betis, they agree well with the larva of $R$. ori$z a b a$; the thoracic dorsal tubercles being no larger than the abdominal ones, this species approaching nearest to $R$. aurota. In $R$. betis, however, no traces of tubercles are given, and in the text it is stated that the larva has no spines; the larva is blackish, banded transversely with deep pink-red. The larvae, then, of the American species hitherto referred to Attacus, appear to present excellent distinctive characters.

Judging by the larvae, whose tubercles are more like those of Samia, Rothschildia is the more primitive type, and Attacus the more specialized. Attacus is in venation and the shape of the wings closely allied to Philosamia (P. cynthia) its larva is more specialized than that of Philosamia; but the latter has begun to be specialized in the reduction of the dorsal tubercles of the prothoracic segment, which are short, rounded, and unarmed.

Attacus is confined to the Oriental region, while the older more primitive genus Philosamia is represented in equatorial Africa as well as the East Indies; it is probable that the Ethiopian realm was the original home of these two genera, unless Attacus separated after migration into the East Indies, India and the East Indian Archipelago. 

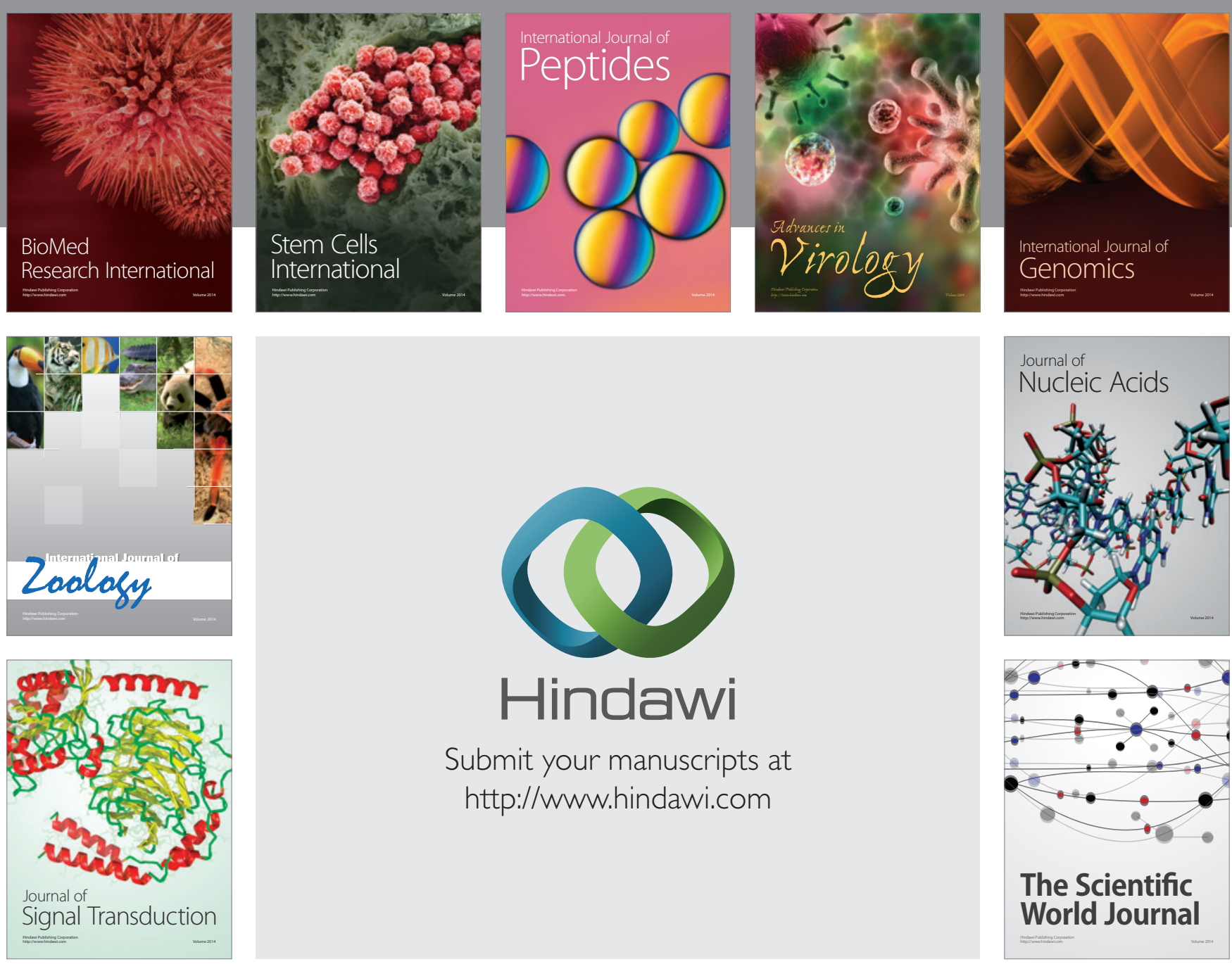

Submit your manuscripts at

http://www.hindawi.com
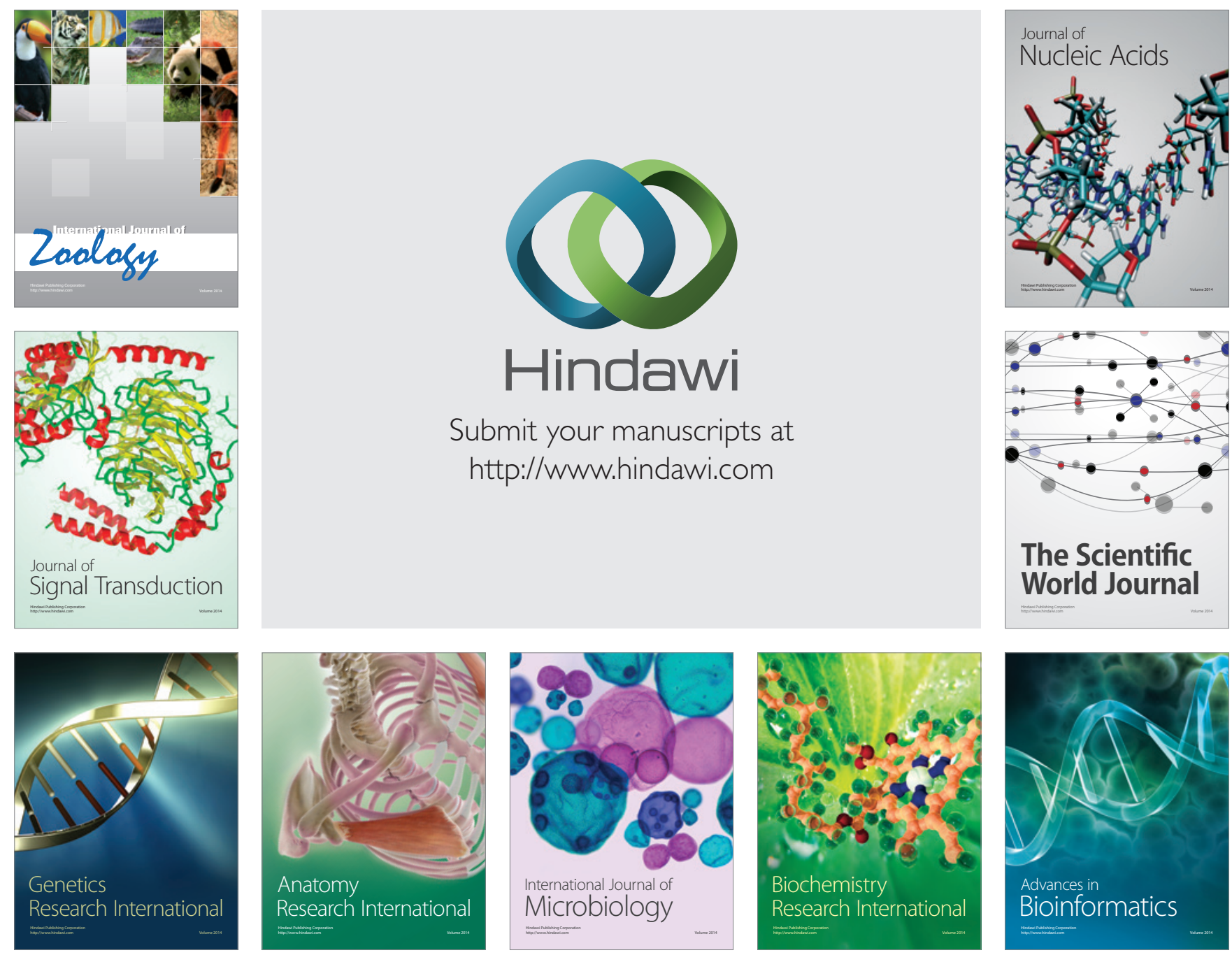

The Scientific World Journal
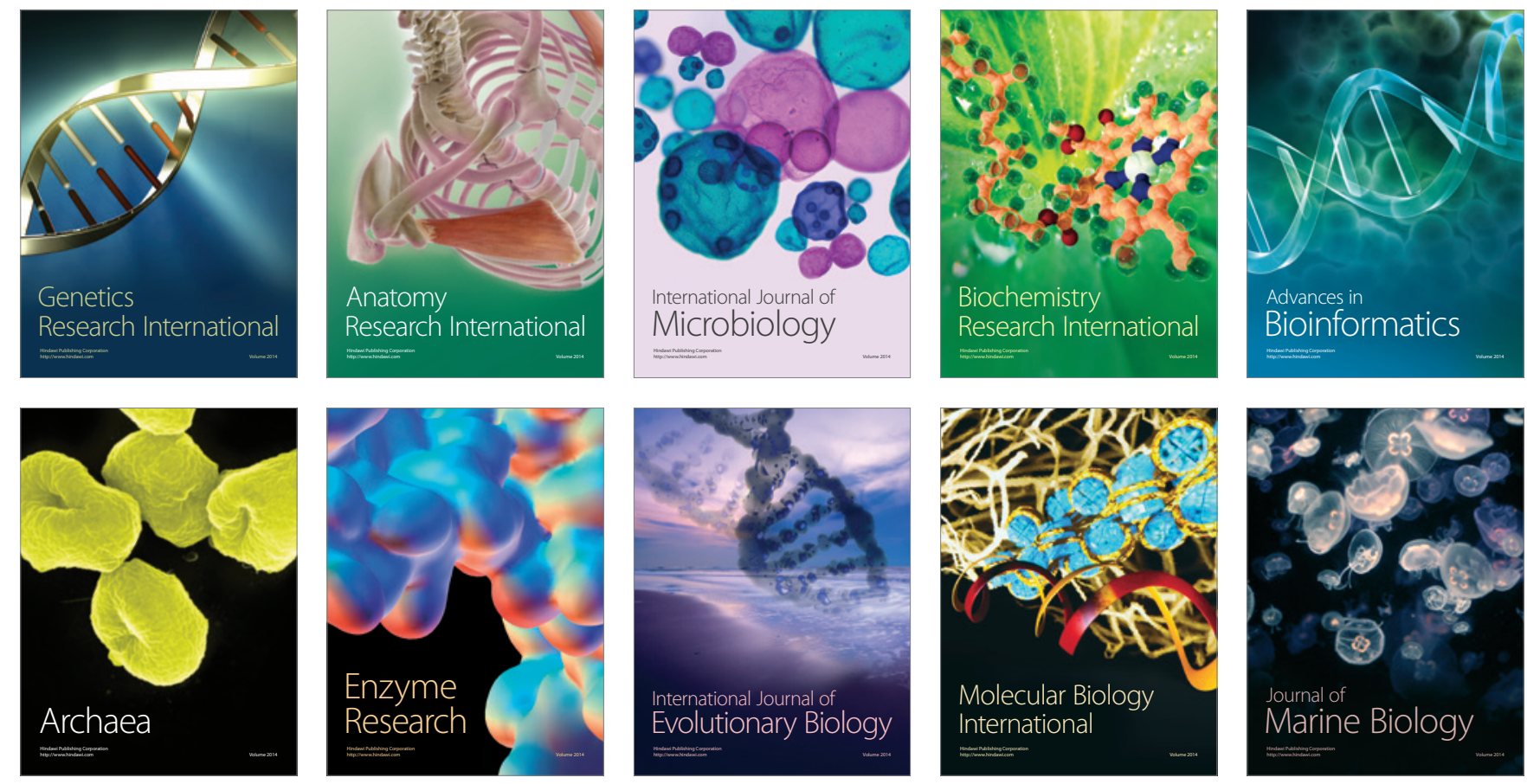